See the Supplement included in Volume XVIII:3, Canadian Journal of Political Science, for details. / Voir les détails dans le supplément inclus dans le Volume XVIII:3 de la Revue canadienne de science politique.

\title{
1986 Essex Scholarships
}

The Canadian Political Science Association hopes again to receive a grant from the Social Sciences and Humanities Research Council of Canada to permit three Canadian members to attend the Summer School in Social Science Data Analysis and Collection held each year at The University of Essex, Colchester, England. The course is sponsored by The Department of Government at Essex and by the European Consortium for Political Research. It is very highly regarded and is attended by Western Europeans and some North Americans.

The Association offers three scholarships, of slightly in excess of $\$ 2,000$ each, to defray the cost of travel, fees and accommodation for the obligatory four-week. stay. The programme takes place in July and August of each year.

The selection committee prefers evidence of a commitment to the political science profession. In practice this would mean that scholarship holders be professors, or students in their doctoral programme, or beyond.

We invite enquiries and will provide those interested with specific information on how to make a formal application. Please write, by January 31, 1986, to The Secretary-Treasurer, Canadian Political Science Association, University of Ottawa, Ottawa, Canada K1N 6 N5.

\section{Bourses d'Études 1986 à The University of Essex}

L'Association canadienne de science politique espère recevoir encore une subvention du Conseil de recherches en sciences humaines du Canada pour permettre à trois de ses membres canadiens de participer au séminaire d'été de The University of Essex à Colchester, Angleterre (The Essex Summer School in Social Science Data Analysis and Collection). Ce séminaire est co-patronné par The Department of Government à The University of Essex et «The European Consortium for Political Research ». Participent à ce seminaire de haut niveau des chercheurs venus d'Europe occidentale et d'Amérique du Nord.

L'Association offre trois bourses d'environ $2000 \$$ destinés à defrayer le coût de voyage, les frais d'inscription, et le logement pour un séjour obligatoire de quatre semaines. Le séminaire a lieu chaque année en juillet-août.

Le comité de sélection accordera la préférence aux etudiant(e)s au moins inscrit(e)s dans leur programme de doctorat, ou aux professeurs. 
Pour tout renseignement, écrire avant le 31 janvier 1986 au Secrétaire-Trésorier, Association canadienne de science politique, Université d'Ottawa, Ottawa, Canada K1N 6 N5.

\section{Travel Grants to Learned Societies' Meetings}

CPSA-Annual General Meeting, University of Manitoba, Winnipeg, Manitoba, June 6, 7, and 8, 1986

The Canadian Political Science Association receives a travel grant from The Social Sciences and Humanities Research Council of Canada to assist members to come to the annual meeting from distant places. These funds are particularly designed to help participating younger members or those participants whose university may be unable to help them defray their costs. They are all apportioned before the meetings take place.

The assumption remains that established assistant, associate, and full professors who are participating as paper-givers, discussants, or chairpersons will be subsidized by their own university. At the date of the final allocation of grants (approximately May 1 of each year) any funds not used by participants will be allocated to junior non-participating members of the Association. We stress this point to planners of the programme who must inform participants of these deadlines.

To be considered, requests for travel funds must reach The Secretary-Treasurer, Canadian Political Science Association, University of Ottawa, Ottawa, Canada K1N 6N5 by April 15, 1986.

Your letter of application must state: (1) that you have approached your own institution for funds; (2) the amount of any partial grants you expect to receive from other sources than the CPSA; (3) your academic rank; (4) whether or not you will be participating in the programme.

Indemnité de déplacement pour les conférences des sociétés savantes ACSP-Réunion annuelle générale, University of Manitoba, Winnipeg, Manitoba, le 6, 7 et 8 juin, 1986

L'Association canadienne de science politique reçoit des fonds du Conseil de recherches en sciences humaines du Canada pour couvrir les frais de déplacement des membres résidant loin de la conférence. Ces allocations sont plus particulièrement destinées aux membresparticipants les plus jeunes ainsi qu'à ceux parmi eux dont l'université ne peut indemniser le déplacement. Les bénéficiaires seront tous désignés avant la réunion. 